\title{
Pensonomonoor
}

2015, vol. 74, 77-84

http://dx.doi.org/10.12657/denbio.074.008

\author{
Domen Gajšek, Kristjan Jarni, Robert Brus
}

\section{Conversion of old black pine stands using broadleaf tree species in the Slovenian Karst}

Received: 11 August 2014; Accepted: 26 June 2015

\begin{abstract}
The conversion of old black pine plantations into ecologically more stable broadleaf forests is an important goal in many Mediterranean countries. Six experimental plots split between more and less productive sites were established in the sub-Mediterranean climate zone of south-western Slovenia in an area of mostly pure black pine stands. In November 2012 they were planted with six native broadleaf species (Celtis australis, Quercus petraea, Fagus sylvatica, Prunus avium, Juglans regia and Acer pseudoplatanus). The test plantations were intended to become small initial nuclei from which the introduced broadleaf species could later spread naturally into the old and partly degraded pine plantations. Seedling condition was assessed one year after planting. Based on their high survival rates after the first growing season, all tested species except F. sylvatica showed promising potential for future conversion of old pine stands in the Slovenian Karst region. However, the results of one growing season only are insufficient to draw firm conclusions. Of all planted species $P$. avium had the highest survival rate $(95 \%)$ and was least susceptible to poor field conditions. Without exception, all species showed lower survival rate on the less productive site. Unlike other species, $P$. avium and $J$. regia seedlings had considerable height increment, while $F$. sylvatica had the lowest. From the results we can assume that perhaps old pine stands in the area have already considerably improved soil conditions and thereby enabled the introduction of broadleaves.
\end{abstract}

Additional key words: planting broadleaves, forest conversion, survival rate, height increment, tree vigour

Addresses: D. Gajšek, K. Jarni, R. Brus, Department of Forestry and Renewable Forest Resources, Biotechnical Faculty, University of Ljubljana, Večna pot 83, 1000 Ljubljana, Slovenia, e-mail: domen. gajsek@bf.uni-lj.si

\section{Introduction}

The Slovenian Karst area was originally covered with deciduous forest; however, with growing demand for wood (especially construction timber, firewood and wood for Venetian and Austrian shipyards), the pressure on forests increased significantly, which lead to their degradation. Grazing of sheep and goats resulted in even further damage to vegetation. In 1825 only $15 \%$ of the Karst was covered with forest, while nowadays $65 \%$ of the area is forested (Kladnik 2011).

The traditional strategy for reforesting degraded lands in the Mediterranean was to first introduce a fast-growing pioneer species, usually a pine species, in order to stop further degradation and facilitate the introduction of either artificial or natural late-successional broadleaves. The success of forest plantations in the Mediterranean is often limited by poor soil conditions, more specifically low root support 
capacity that reduces the amount of available water and nutrients. Consequently, soil preparation is often needed to increase soil depth and availability of water and nutrients.

Afforestation of the Karst region in south-western Slovenia began as early as 1859 , when the first successful black pine (Pinus nigra Arnold) plantations were established under the guidance of Josip Koller (Kladnik et al. 2008). Black pine is irreplaceable in the processes of degraded site re-cultivation in the Croatian Mediterranean (Matić et al. 2011). Between 1850 and 1915, 10,842 ha of almost barren Karst was afforested in the area of present-day Slovenia. During World War I the afforestation almost stopped. In the period 1915-1945, only 850 ha was afforested and between 1945-1954 it increased again, to about 4000 ha (Gašperšič and Winkler 1986). Over time, Karst black pine plantations improved site conditions considerably. However, these large and homogenous plantations (covering an area of 16,500 ha, see Diaci et al. 2014) are now increasingly threatened by pests, such as pine processionary (Thaumetopoea pityocampa), pine shoot moth (Rhyacionia buoliana), common pine sawfly (Diprion pini), and european pine sawfly (Neodiprion sertifer), and diseases, such as sphaeropsis blight (Diplodia pinea), Cenangium ferruginosum, and Sydowia polyspora (Jurc and Jurc 2014). Moreover, these networks of pine plantations interconnected through agricultural land have a high fire hazard and have facilitated the spread of large fires in the last decades. Due to improved soil conditions many black pine plantations are now being gradually colonized by the natural succession of native tree species such as Fraxinus ornus, Ostrya carpinifolia, Prunus mahaleb and occasionally Quercus pubescens. However, considering the long-term effects, modern landscape and forest management, and the current social demands on forests, these species might not fully meet our expectations for timber quality, multi-purpose use, or succession direction and speed. Therefore, in addition to natural succession, a variety of possible approaches are being considered for gradually converting pine plantations and accelerating the development of stands with desired species structure. Broadleaf species are very suitable in sustainable and multi-purpose forest management as they significantly contribute to forest biodiversity, are less susceptible to fire risk and diseases, may play an important role in the upcoming climate changes and, according to some authors, are more popular than conifers from a recreational standpoint (Colson et al. 2010).

In Europe, since the early 1990s broadleaf plantations have been promoted financially as multifunctional forests for biodiversity, timber production and recreation, while conifers had been predominately used until then (Brunet 2007). As a result, EU af- forestation incentives (EEC 2080/92) have yielded more than 0.5 million ha of newly established broadleaved forest across Western Europe (Report to... 1997). In the USA, the demand for hardwood seedlings is increasing (Jacobs et al. 2004), and, moreover, some studies have shown that the public mainly prefers broadleaves over conifers, mostly for their appearance (O'Leary et al. 2000).

There is a noticeable lack of studies regarding using broadleaves for forest conversion in the Mediterranean and in karst areas in particular. Quantified survival rates for various planted broadleaf species are particularly rare. Because of the lack of studies on this subject, it is essential to obtain local experience and knowledge based on which the successful conversion of existing black pine plantations would be feasible. Since the conversion of such large areas is an expensive measure, a detailed assessment of various possible tree species and their starting success is crucial. The introduction of desired broadleaves can be achieved either by direct planting of seedlings over large areas, or preferably, due to lower costs, through establishing small initial nuclei from which the introduced tree species can spread naturally into old and partly degraded pine stands over time. To the best of our knowledge this idea has not yet been tested in any other research in this way. Selected broadleaf species must be suitable both for establishing plantations as well as for forming future immigration nuclei while at the same time ensuring the multifunctional role of the forest. Most newly planted trees are subject to stress-related problems due to serious root loss when dug at the nursery. This condition, commonly known as transplant shock, results in increased vulnerability to drought, insects and diseases. To a greater or lesser degree, transplant shock lasts until the natural balance between the root system and the top or crown of the transplanted tree is restored. Of those newly planted trees that do not survive, most die during this root-establishment period. The survival of seedlings in the first year after planting is crucial when establishing forest plantations (Maestre et al. 2003), with the first summer being the most important period in terms of survival (Ceacero et al. 2012).

The goal of our study was to examine the suitability of various broadleaf tree species for the purpose of conversion of old black pine stands in the Slovenian Karst by assessing seedling survival rate, height increment and vigour after the first growing season.

\section{Materials and Methods}

\section{Study area}

In 2012 six experimental plots, each $50 \times 100 \mathrm{~m}$ in size, were established within old black pine stands 
Table 1. Main characteristics of the experimental plots

\begin{tabular}{|c|c|c|c|c|c|c|}
\hline Plot No. & Coordinates & Site & Site Index $\left(\mathrm{SI}_{100}\right)$ & Altitude (m) & Inclination $\left(^{\circ}\right)$ & Rockiness (\%) \\
\hline 1 & $\begin{array}{l}45^{\circ} 41^{\prime} 17.05^{\prime \prime N} \\
13^{\circ} 58^{\prime} 49.31^{\prime \prime E}\end{array}$ & \multirow{3}{*}{1} & \multirow{3}{*}{21} & \multirow{3}{*}{441} & \multirow{3}{*}{$0-5$} & \multirow[t]{3}{*}{ 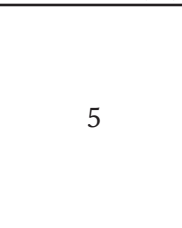 } \\
\hline 2 & $\begin{array}{l}45^{\circ} 41^{\prime} 13.66^{\prime \prime} \mathrm{N} \\
13^{\circ} 58^{\prime} 57.74^{\prime \prime} \mathrm{E}\end{array}$ & & & & & \\
\hline 3 & $\begin{array}{l}45^{\circ} 41^{\prime} 16.86 " \mathrm{~N} \\
13^{\circ} 58^{\prime} 56.65^{\prime \prime} \mathrm{E}\end{array}$ & & & & & \\
\hline 4 & $\begin{array}{l}45^{\circ} 42^{\prime} 08.79^{\prime \prime} \mathrm{N} \\
13^{\circ} 59^{\prime} 31.70^{\prime \prime} \mathrm{E}\end{array}$ & \multirow{3}{*}{2} & \multirow{3}{*}{18} & \multirow{3}{*}{$541-642$} & \multirow{3}{*}{15} & \multirow{3}{*}{10} \\
\hline 5 & $\begin{array}{l}45^{\circ} 42^{\prime} 11.62^{\prime \prime} \mathrm{N} \\
13^{\circ} 59^{\prime} 31.83^{\prime \prime} \mathrm{E}\end{array}$ & & & & & \\
\hline 6 & $\begin{array}{l}45^{\circ} 42^{\prime} 15.16^{\prime \prime} \mathrm{N} \\
13^{\circ} 59^{\prime} 25.44^{\prime \prime} \mathrm{E}\end{array}$ & & & & & \\
\hline
\end{tabular}

in the Slovenian Karst near the town of Divača in the sub-Mediterranean climate zone. The prevailing potential vegetation on all plots was the forest association Seslerio-Ostryetum and the altitude ranged between 400 and $650 \mathrm{~m}$. All plots were located on limestone bedrock with rendzina soil. The mean air temperature in 2013 was $12.2^{\circ} \mathrm{C}$, while the mean maximum temperature was $17.6^{\circ} \mathrm{C}$. Total annual precipitation amounted to $1492 \mathrm{~mm}$ and the total solar radiation was 2159.7 hours. The summer of 2013 was extremely hot, and in some places, new temper- ature records were reached. In the area of our study, the average maximum temperature for July and $\mathrm{Au}$ gust 2013 was $30.3^{\circ} \mathrm{C}$ while it was only $26^{\circ} \mathrm{C}$ in 2014 (ARSO, 2014). On the first three plots, which were located on flat terrain, growing conditions were considerably better than those on the second three plots (see Site Index - Table 1), which were located on a slope and at higher altitude. The group of the first three plots was named the more productive site (Site 1 ) and the group of the second three plots the less productive site (Site 2) (Table 1, Fig. 1).

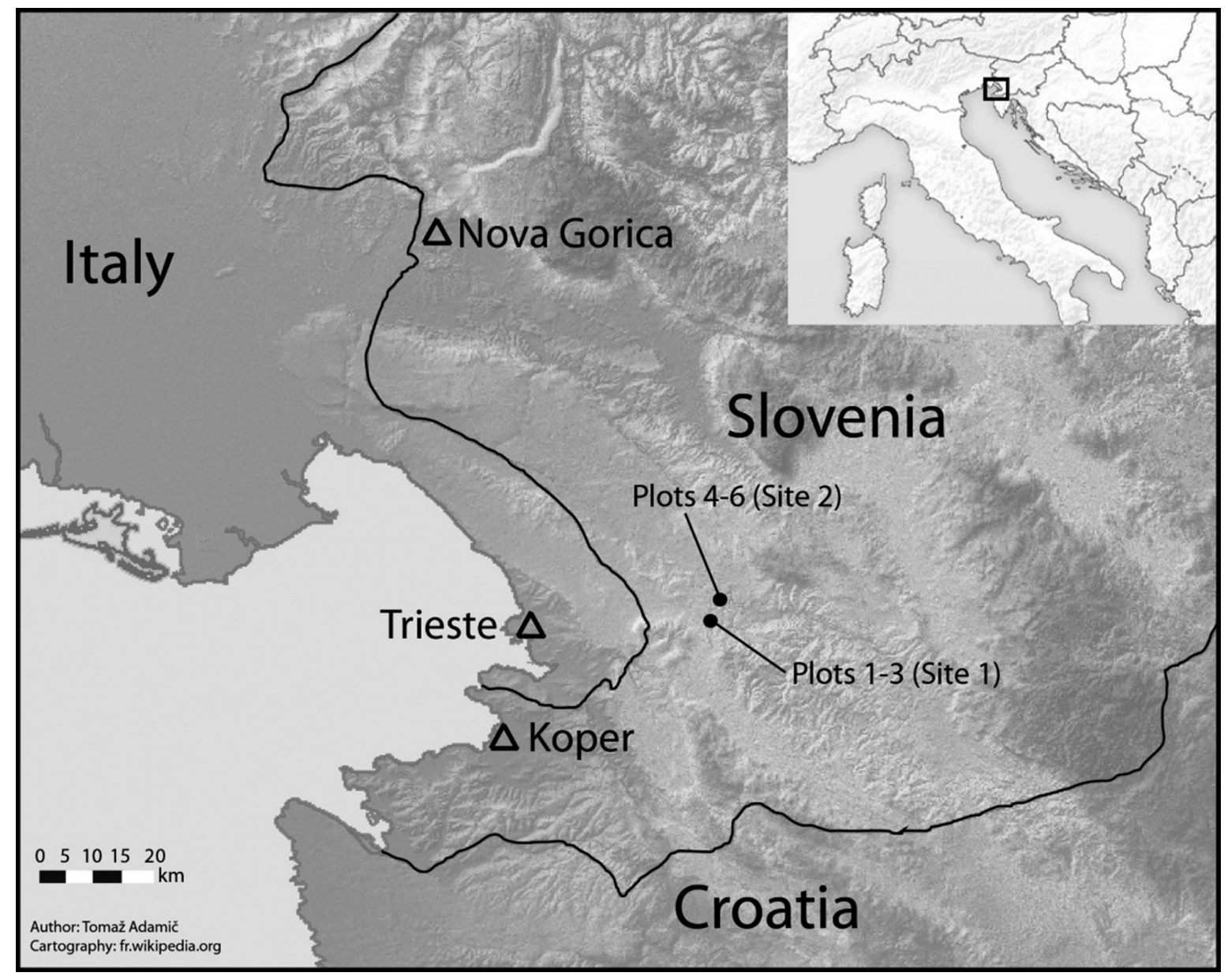

Fig. 1. Locations of the studied plots 


\section{Methodology}

On all research plots, old black pines were first cut down, followed by site preparation consisting of the removal of some bigger stumps and the removal of excess vegetation. Finally, a $45 \times 80 \mathrm{~m}$ metal mesh fence was installed on each plot. Six broadleaf tree species were included in the trial: European nettle tree (Celtis australis L.), sessile oak (Quercus petraea (Mattuschka) Liebl.), European beech (Fagus sylvatica L.), wild cherry (Prunus avium L.), common walnut (Juglans regia L.) and sycamore maple (Acer pseudoplatanus L.). With the aim of testing a variety of ecologically diverse species, the six selected species intentionally cover a somewhat wider ecological range of broadleaves and not only thermophilic species, which would be the most obvious choice. C. australis seedlings were container bred, seedlings of $F$. sylvatica came from natural regeneration and were further bred in a nursery, while seedlings of all other species were bare rooted. Seedlings of $A$. pseudoplatanus and $P$. avium were both taller than $110 \mathrm{~cm}$ on average. $F$. sylvatica, J. regia and C. australis seedling height was between 60 and $90 \mathrm{~cm}$, while $Q$. petraea seedlings were around $25 \mathrm{~cm}$ in height.

Planting was carried out in November 2012. Seedlings were planted into manually dug holes at $2 \mathrm{~m}$ intervals. Each of the six species was planted in five successive lines with 14-17 seedlings per individual line. The position of the individual species within the plot was randomized. On average, 478 seedlings of each species were planted in all six plots (approximately 80/plot). An unplanted strip of land was left on every plot for control. In October 2013, after the end of the first growing season, a survey of seedling condition was performed. The height and the height increment of seedlings were measured. We determined the seedling's survival ( 0 dead, 1 alive) and calculated the survival rate (given as percentage) for each species. For vigour assessment a 3-level scale was used ( 1 - good vigour; 2 - medium vigour; and 3 - low vigour). When determining the differences in height increment of the seedlings and association between survival rate, vigour and plots and sites, we used the terms "within site" and "between sites". The term "within site" was used when analysing the differences within the first or second group of plots while the term "between sites" was used when analysing the differences between the two groups of plots. In order to determine whether shading from the surrounding remaining old pine trees had any influence on survival rate of seedlings, every plot was divided into four rectangular strips of equal width so that the first quarter was always located at the northern part of each plot, the fourth quarter at the southern part, while the second and third quarter were in between the two.

\section{Statistics}

Differences in the annual height increment of seedlings among individual plots and between sites were tested with the Kruskal-Wallis and Mann-Whitney U-test respectively. The Chi-Square test was used to test the association between survival rate and vigour of seedlings on one hand and plots and sites on the other. The Chi-Square test was also used to determine the relationship between shading of the surrounding old trees and survival rate of seedlings. All tests were performed with IBM ${ }^{\circledR}$ SPSS ${ }^{\circledR}$ Statistics.

\section{Results}

The species with the highest survival rate after the first growing season was P. avium (95\%), followed by J. regia (92\%) and C. australis (91\%), while F. sylvatica had by far the lowest survival rate of all planted species $(44 \%)$ (Table 2 ). All species without exception showed lower survival rate on the less productive site, with $P$. avium showing the smallest difference in survival rate between the two sites and A. pseudoplatanus the largest. The survival rate of $P$. avium also had the smallest coefficient of variation $(2.9 \%)$ of all the species (Table 2). Considering the harsh conditions (extremely hot summer in 2013), the survival rate of

Table 2. Summary table of main studied parameters for all species on both sites

\begin{tabular}{lcccccc}
\hline & Site & Celtis australis & Quercus petraea & Fagus sylvatica & Prunus avium & Juglans regia \\
& 1 & 99 & 94 & 55 & 97 & 97 \\
pseudoplatanus
\end{tabular}

${ }^{1}$ mode of vigour 
Table 3. Chi-Square test of survival rate and vigour along with Kruskal-Wallis and Mann-Whitney U-test of increment for all species on both sites

\begin{tabular}{|c|c|c|c|c|c|c|c|}
\hline & \multirow[b]{2}{*}{ Site } & \multicolumn{2}{|c|}{ Survival rate } & \multicolumn{2}{|c|}{ Vigour } & \multicolumn{2}{|c|}{ Increment } \\
\hline & & $\begin{array}{c}\mathrm{p} \\
\text { (within } \\
\text { sites) }\end{array}$ & $\begin{array}{c}\mathrm{p} \\
\text { (between } \\
\text { sites) }\end{array}$ & $\begin{array}{c}\mathrm{p} \\
\text { (within } \\
\text { sites) }\end{array}$ & $\begin{array}{c}\mathrm{p} \\
\text { (between } \\
\text { sites) }\end{array}$ & $\begin{array}{c}\mathrm{p} \\
\text { (within } \\
\text { sites) }\end{array}$ & $\begin{array}{c}\mathrm{p} \\
\text { (between } \\
\text { sites) }\end{array}$ \\
\hline \multirow{2}{*}{ Celtis australis } & 1 & 0.048 & \multirow{2}{*}{0.000} & 0.391 & \multirow{2}{*}{0.000} & 0.059 & \multirow{2}{*}{0.171} \\
\hline & 2 & 0.010 & & 0.003 & & 0.089 & \\
\hline \multirow{2}{*}{ Quercus petraea } & 1 & 0.586 & \multirow{2}{*}{0.000} & 0.337 & \multirow{2}{*}{0.000} & 0.454 & \multirow{2}{*}{0.650} \\
\hline & 2 & 0.080 & & 0.414 & & 0.232 & \\
\hline \multirow{2}{*}{ Fagus sylvatica } & 1 & 0.125 & \multirow{2}{*}{0.000} & 0.411 & \multirow{2}{*}{0.453} & 0.008 & \multirow{2}{*}{0.000} \\
\hline & 2 & 0.000 & & 0.133 & & 0.726 & \\
\hline \multirow{2}{*}{ Prunus avium } & 1 & 0.405 & \multirow{2}{*}{0.273} & 0.065 & \multirow{2}{*}{0.000} & 0.036 & \multirow{2}{*}{0.814} \\
\hline & 2 & 0.419 & & 0.000 & & 0.000 & \\
\hline \multirow{2}{*}{ Juglans regia } & 1 & 0.601 & \multirow{2}{*}{0.000} & 0.032 & \multirow{2}{*}{0.000} & 0.623 & \multirow{2}{*}{0.000} \\
\hline & 2 & 0.007 & & 0.002 & & 0.318 & \\
\hline \multirow{2}{*}{ Acer pseudoplatanus } & 1 & 0.033 & \multirow{2}{*}{0.000} & 0.737 & \multirow{2}{*}{0.000} & 0.094 & \multirow{2}{*}{0.047} \\
\hline & 2 & 0.000 & & 0.793 & & 0.394 & \\
\hline
\end{tabular}

P. avium, J. regia and C. australis after the first growing season can be rated as high, that of $Q$. petraea and $A$. pseudoplatanus as moderate, and that of $F$. sylvatica as low.

Of all studied species, $F$. sylvatica had the smallest annual height increment $(2.5 \mathrm{~cm}$ on average), while J. regia had the largest, which was quite considerable (20.5 $\mathrm{cm}$ on average). The differences in increment for $J$. regia and $P$. avium between the more and less productive site were not particularly large. The vigour of $Q$. petraea, P. avium and J. regia noticeably deteriorated when comparing the more productive to less productive site, whereas the other species largely retained the same vigour between the two sites (Table 2).

We found significant association $(p<0.001)$ between survival rate and site for all species except $P$. avium (Table 3). For species C. australis, F. sylvatica, $J$. regia and $A$. pseudoplatanus, significant association was found between their survival rate and plot. For $C$. australis and $A$. pseudoplatanus significant association was found between survival rate and all plots, while for F. sylvatica and J. regia it was found only for the less productive site. Regarding survival rate, $P$. avium noticeably stood out with no association either with plots or sites. Likewise, no such relationship was found between plots and survival rate of $Q$. petraea, though it was found $(p<0.001)$ between the sites and its survival rate (Table 3 ).

Significant association $(p<0.001)$ between the seedling vigour and sites was found for all species except F. sylvatica, as its survival was poor on both sites (Table 2). Significant relationship between the vigour of the seedlings and plots was found for J. regia, while for $C$. australis and $P$. avium this relationship was confirmed only in the case of the less productive site. As regards both survival rate and vigour, Q. petraea behaved in the same way: significant association $(p<0.001)$ between site and survival rate/vigour, while a relationship between plot and survival rate/ vigour was not confirmed (Table 3 ).

We found significant differences in seedling height increment among plots within the more productive site for F. sylvatica and among all plots on both sites for $P$. avium. Between the sites, significant differences in seedling height increment were found for F. sylvatica, J. regia and A. pseudoplatanus, while for Q. petraea, we did not find any differences (Table 3 ).

Table 4 shows the results of species' survival rate after dividing each plot by quarters as to determine

Table 4. Average survival rate and Chi-Square test of survival rate divided by quarters (1st quarter - northern part of each plot, 4th quarter - southern part) for all species on both sites

\begin{tabular}{|c|c|c|c|c|c|c|c|c|c|c|}
\hline & \multicolumn{5}{|c|}{ Site 1 (Plots 1-3) } & \multicolumn{5}{|c|}{ Site 2 (Plots 4-6) } \\
\hline & \multicolumn{4}{|c|}{ Survival rate $(\%)$} & \multirow{2}{*}{$\mathrm{p}$} & \multicolumn{4}{|c|}{ Survival rate $(\%)$} & \multirow{2}{*}{$\mathrm{p}$} \\
\hline & 1 & 2 & 3 & 4 & & 1 & 2 & 3 & 4 & \\
\hline Celtis australis & 100 & 100 & 100 & 95 & 0.028 & 82 & 83 & 92 & 78 & 0.223 \\
\hline Quercus petraea & 95 & 90 & 100 & 92 & 0.095 & 72 & 73 & 57 & 83 & 0.016 \\
\hline Fagus sylvatica & 40 & 57 & 60 & 65 & 0.039 & 47 & 25 & 30 & 26 & 0.038 \\
\hline Prunus avium & 93 & 93 & 100 & 100 & 0.041 & 92 & 98 & 90 & 93 & 0.290 \\
\hline Juglans regia & 98 & 98 & 97 & 97 & 0.885 & 90 & 85 & 88 & 86 & 0.854 \\
\hline Acer pseudoplatanus & 92 & 93 & 98 & 90 & 0.281 & 58 & 77 & 60 & 57 & 0.085 \\
\hline
\end{tabular}


whether shading of surrounding old pine trees had any influence on seedling survival rate. The shading from old pines was presumably more noticeable on the southern quarter (4) of each plot and less noticeable on the remaining three quarters. We found that such was the case with F. sylvatica (shade-loving plant), whose survival rate was lowest at the northern quarter (1) and then gradually improved before becoming highest at the southern quarter (4), where shading was presumably most noticeable (Table 4). The survival rate distribution of $F$. sylvatica was almost the opposite on the less productive site, with the highest survival rate found on the northern quarter (1). The association between survival rate and plot quarters on the more productive site was significant for F. sylvatica. On the same site (Site 1), survival rate of other species did not vary much from one quarter to another; however, this relationship was also significant for $C$. australis and P. avium. Even though the distribution of survival rate for most species was more uneven and without any noticeable trend on the less productive site (Site 2), significant association was found for Q. petraea and F. sylvatica.

\section{Discussion}

When establishing forest plantations, the survival of seedlings in the first year after planting and in the few successive years is crucial. In our experiment, after the first growing season and considering the harsh conditions of the area under analysis, the results showed moderate to high survival rate for most of the tested species, which could possibly indicate that the species used are promising for the purpose of converting old pine stands in the Slovenian Karst. The introduction of broadleaves into pine plantations should not begin until the soil conditions have already been considerably improved by conifers, which seems to be an unavoidable succession step in the restoration of degraded karst land, which is in line with the findings of Matić et al. (2011). However, F. sylvatica is an exception due to its insufficient survival rate. The poor results of this species are difficult to interpret. They might be attributed to the species' low resistance to summer water stress, especially in a summer as extreme as that of 2013, as well as to the generally poor quality of its seedlings and the fact that they came from natural regeneration and may have undergone some shock when transferred from a shaded environment to full sun. This is in line with findings of Tabari et al. (2005) who found that Fagus orientalis seedlings from natural regeneration that grew under the canopy until transplanting had growth difficulties under direct light that manifested in decreased shoot growth with increasing gap size. Johnson et al. (1997) stated that the growth of container bred F. sylvatica seedlings was better in small gaps than in the understory or clearings. According to Jarčuška (2009), the growth of $F$ sylvatica in natural regeneration mostly depends on belowground resources in the first year. The poor quality of its seedlings might have also been the cause for much of the seedling mortality. According to Grossnickle (2012), factors affecting seedling physiological quality, such as stress resistance and nutritional status, bear a major influence on survival. Regarding the quality of the soil on the other hand, Don et al. (2007) could not find any correlation between soil quality and seedling establishment success or survival rate for F. sylvatica or Q. petraea. Comparing our species' survival rates to those from other studies that dealt with some of the same species, we see that $P$. avium seedlings in our study had a survival rate of $95 \%$ after the first growing season, while in a study from Turkey seedling survival rate was $77 \%$ after the second growing season (Esen et al. 2012). A study from Germany also cites low survival rates for F. sylvatica (from 21\%) in the first three years after planting (Don et al. 2007). For Q. petraea the same study cites a survival rate between 39 and $81 \%$, while it amounted to $83 \%$ in our study. The survival rates of $C$. australis from our study and the study of Topić (1997) were almost the same $(91 \%$ and $92.5 \%$, respectively) after the first year since planting.

Unfavourable field conditions at the less productive site are the likely reason for the lower survival rates of the seedlings growing there. The terrain is considerably steeper with more rocky ground and a shallower soil layer. It is less protected from surrounding old black pine stands and thus more exposed to winds and more prone to sunburn. The survival rates between the two sites varied significantly from one species to another. P. avium was the least susceptible to poor field conditions. This might indicate its somewhat higher ecological amplitude, especially when compared to A. pseudoplatanus, which had the largest drop in survival rate from the more to less productive site. However, these differences may also be in part a result of differences in seedling quality between species and could diminish in the coming years.

The considerably larger height increment of $P$. avi$u m$ and J. regia seedlings compared to that of all other species is also likely a result of better quality seedlings, which were sturdy and well-rooted at the time of planting. The height of seedlings at the time of planting did not seem to be relevant; for instance, despite the fact that seedlings of $A$. pseudoplatanus were among the tallest, their increment after first year was quite small.

The exception and higher ecological amplitude of $P$. avium was once again proven in statistical analysis of association between survival rate and plots/sites as no such relationship was found for this species. Determining the reasons why P. avium performed so well 
in all conditions would necessarily require further research. After F. sylvatica (with its exceptionally poor results), A. pseudoplatanus seedling survival rate had the greatest variability, which makes the species seem rather susceptible to small-scale, local micro conditions. Seedlings of $Q$. petraea behaved more uniformly within each of the two sites regarding both survival rate and vigour, but differed between the sites.

We also tested whether shading from the surrounding old pine trees had any influence on the survival rate of the seedlings in the first year. Some studies show that $F$. sylvatica seedlings have high probability of survival not only at low but also at high levels of light (Kunstler et al. 2005). According to Ammer (2002), F. sylvatica shows a strong decrease in growth with decreasing light quantity, but although it has a high survival rate under low light, it also has a low growth rate under high light (Petritan et al. 2007). Our results showed no clear shading effect from the surrounding trees on seedling survival rate, not even at the more productive site where the terrain is flat and the surrounding trees are taller. We assume that this impact will probably be seen in the coming years.

In conclusion, based on their high survival rates after the first growing season, all tested species ( $P$. avium, J. regia and C. australis in particular) except $F$. sylvatica showed promising potential for use in future direct or indirect conversion of old pine stands in the Karst region. However, the results after the first growing season are insufficient to draw firm conclusions. Of all planted species $P$. avium had the highest survival rate and was least susceptible to poor field conditions. Without exception, all species showed lower survival rate on the less productive site. Unlike other species, $P$. avium and $J$. regia seedlings had considerable height increment, while $F$. sylvatica had the lowest. We can assume that perhaps old pine stands in the area already considerably improved soil conditions and thereby enabled the introduction of broadleaves.

\section{Acknowledgements}

This research was supported by the research project V4-1124 financed by the Slovenian Research Agency and the Ministry of Agriculture and the Environment as well as the research programme P4-0059 and the Pahernik foundation. We thank Andrej Lumbar, Tomaž Adamič, Milan Race, Boštjan Košiček, Edvin Drobnjak, Branka Gasparič and Ivan Dolenc for their help in setting up the trial and conducting the field work. We thank all forestry students who helped plant the seedlings. We also thank Aleš Kadunc for providing Site Index data.

\section{References}

Ammer C. 2003. Growth and biomass partitioning of Fagus sylvatica L. and Quercus robur L. seedlings in response to shading and small changes in the R/FR-ratio of radiation. Annals of Forest Science 60: 163-171.

ARSO. 2014. Archival data on meteorological conditions in Slovenia. Slovenian Environment Agency. Ministry of the Environment and Spatial Planning, Ljubljana, Slovenia. http://meteo.arso.gov. $\mathrm{si} / \mathrm{met} / \mathrm{sl} /$ archive/ (31.3.2015).

Brunet J. 2007. Plant colonization in heterogeneous landscapes: an 80-year perspective on restoration of broadleaved forest vegetation. Journal of Applied Ecology 44: 563-572.

Ceacero C.J., Díaz-Hernández J.L., del Campo A.D., Navarro-Cerrillo R.M. 2012. Interactions between soil gravel content and neighboring vegetation control management in oak seedling establishment success in Mediterranean environments. Forest Ecology and Management 271: 10-18.

Colson V., Garcia S., Rondeux J., Lejeune P. 2010. Map and determinants of woodlands visiting in Wallonia. Urban Forestry \& Urban Greening 9: 83-91.

Diaci J., Adamič T., Grce D., Rozman A., Roženbergar D. 2014. Premena kraških gozdov črnega bora (Pinus nigra J.F. Arnold) z naravno obnovo. In: XXXI. Gozdarski študijski dnevi: Premene malodonosnih in vrstno spremenjenih Gozdom. Roženbergar D. (ed.). Ljubljana.

Don A., Arenhövel W., Jacob R., Scherer-Lorenzen M., Schulze E.D. 2007. Anwuchserfolg von 19 verschiedenen Baumarten bei Erstaufforstungen - Ergebnisse eines Biodiversitätsexperimen. (Establishment success of 19 different tree species on afforestations - Results of a biodiversity experiment). Allgemeine Forst und Jagdzeitung 178: 164-172.

Esen D., Yildiz O., Esen U., Edis S., Cetintas C. 2012. Effects of cultural treatments, seedling type and morphological characteristics on survival and growth of wild cherry seedlings in Turkey. iForest-Biogeosciences and Forestry 5: 283-289.

Gašperšič F., Winkler I. 1986. Ponovna ozelenitev in gozdnogospodarsko aktiviranje slovenskega krasa. Gozdarski vestnik 44: 169-184.

Grossnickle S.C. 2012. Why seedlings survive: Influence of plant attributes. New Forests 43: 711-738.

Jacobs D.F., Wilson B.C., Davis A.S. 2004. Recent trends in hardwood seedling quality assessment. In: Proceedings of the conference; Forest and Conservation Nursery Associations-2006. Riley L.E., Dumroese R.K. and Landis T.D (eds.). Ogden, UT: USDA Forest Service, Rocky Mountain Research Station. Proceedings RMRS-P-33: 140-144. 
Jarčuška B. 2009. Growth, survival, density, biomass partitioning and morphological adaptations of natural regeneration in Fagus sylvatica. A review. Dendrobiology 61: 3-11.

Johnson J.D., Tognetti R., Michelozzi M., Pinzauti S., Minotta G., Borghetti M. 1997. Ecophysiological responses of Fagus sylvatica seedlings to changing light conditions. II. The interaction of light environment and soil fertility on seedling physiology. Physiologia Plantarum 101: 124-134.

Jurc D., Jurc M. 2014. Pa so padali bolestno, nemo, bor za borom... - boru na Krasu so šteti dnevi. In: XXXI. Gozdarski študijski dnevi. Premene malodonosnih in vrstnospremenjenih gozdov. Roženbergar D. (ed.). Ljubljana, pp. 27-29.

Kladnik D., Petek F., Urbanc M. 2008. Pogozdovanje in ogozdovanje. In: Kras : trajnostni razvoj kraške pokrajine. Luthar O., Dobrovoljc H., Fridl J., Mulec J., Pavšek M. (eds.). Založba ZRC. Ljubljana (Ljubljana : Littera picta).

Kladnik D. 2011. Širjenje gozda na krasu kot dejavnik prostorskega razvoja. Geografski vestnik 83: 6780.

Kunstler G., Curt T., Bouchaud M., Lepart J. 2005. Growth, mortality, and morphological response of European beech and downy oak along a light gradient in sub-Mediterranean forest. Canadian Journal of Forest Research 35: 1657-1668.

Maestre F.T., Cortina J., Bautista S., Bellot J., Vallejo V.R. 2003. Small-scale environmental hetero- geneity and spatiotemporal dynamics of seedling establishment in a semiarid degraded ecosystem. Ecosystems 6: 630-643.

Matić S., Anić I., Oršanić M., Drvodelić D., Topić V., Mikac S., Đurđević Z. 2011. Afforestation in the Croatian Mediterranean region. Forests of the Croatian Mediterranean. Academy of Forestry Sciences, Zagreb, pp. 411-426.

O'Leary T.N., McCormack A.G., Clinch J.P. 2000. Afforestation in Ireland - regional differences in attitude. Land Use Policy 17: 39-48.

Petritan A.M., Lüpke B.V., Petritan I.C. 2007. Effects of shade on growth and mortality of maple (Acer pseudoplatanus), ash (Fraxinus excelsior) and beech (Fagus sylvatica) saplings. Forestry 80: 397-412.

Report to the European parliament and the council on the application of regulation (EEC) No. 2080/92 instituting a community aid scheme for forestry measures in agriculture. COM (97) 630 final, Brussels, 28. 11. 1997. (EU Commission COM Document) http://aei.pitt.edu/47273/1/ COM_\%2897\%29_630_final.pdf (7. 7. 2014).

Tabari M., Fayaz P., Espahb̄odi K., Staelens J., Nachtergale L. 2005. Response of oriental beech ( $\mathrm{Fa}$ gus orientalis Lipsky) seedlings to canopy gap size. Forestry 78: 443-450.

Topić V. 1997. Upotrebljivost autoktonih listača pri pošumljavanju krša (Usage of native decidous plants for Karst Afforestation). Šumarski list 7-8: 343-352. 